\title{
Osmotic stress sensitizes naturally resistant cells to TNF- $\alpha$-induced apoptosis
}

\author{
DL Franco ${ }^{1}$, IM Nojek², L Molinero ${ }^{3}$, OA Coso ${ }^{1,4}$ and \\ MA Costas ${ }^{\star 1,2,4}$ \\ ${ }^{1}$ Laboratorio de Fisiología y Biología Molecular, Departamento de Cs. \\ Biológicas, Facultad de Ciencias Exactas y Naturales, Universidad de Buenos \\ Aires, Ciudad Universitaria, Pabellón II, C1428EHA Bs. As., Argentina \\ 2 Laboratorio de Biología Molecular y Apoptosis, Departamento de Sustancias \\ Vasoactivas, Instituto de Investigaciones Médicas A. Lanari, Universidad de \\ Buenos Aires, Combatientes de Malvinas 3150, C1427 Bs. As., Argentina \\ ${ }^{3}$ Laboratorio de Inmunogenética. Hospital Nacional de Clínicas 'José de San \\ Martin', Facultad de Medicina, Universidad de Buenos Aires \\ * Corresponding author: MA Costas, Laboratorio de Biología Molecular y \\ Apoptosis, Departamento de Sustancias Vasoactivas, Instituto de \\ Investigaciones Médicas A. Lanari, Universidad de Buenos Aires, \\ Combatientes de Malvinas 3150, C1427 Bs. As., Argentina. \\ Fax: 54-11-4523-8947; E-mail: mcostas@bg.fcen.uba.ar \\ ${ }^{4}$ Member of the Argentine National Research Council (CONICET)
}

Received 26.9.01; revised 4.3.02; accepted 23.4.02

Edited by CJ Thiele

\begin{abstract}
Most cells are naturally resistant to TNF- $\alpha$-induced cell death and become sensitized when NF- $\kappa$ B transactivation is blocked or in the presence of protein synthesis inhibitors that prevent the expression of anti-apoptotic genes. In this report we analyzed the role of osmotic stress on TNF- $\alpha$-induced cell death. We found that it sensitizes the naturally resistant HeLa cells to TNF- $\alpha$-induced apoptosis, with the involvement of an increase in the activity of several kinases, the inhibition of $\mathrm{Bcl}-2$ expression, and a late increase on NF- $\kappa B$ activation. Cell death occurs regardless of the enhanced NF- $k$ B activity, whose inhibition produces an increase in apoptosis. The inhibition of p38 kinase, also involved in NF- $\kappa$ B activation, significantly increases the effect of osmotic stress on TNF- $\alpha$-induced cell death.

Cell Death and Differentiation (2002) 9, 1090-1098. doi:10.1038/sj.cdd.4401074
\end{abstract}

Keywords: apoptosis; NF- $\kappa$ B; TNF- $\alpha$; MAP kinases

Abbreviations: TNF- $\alpha$, tumor necrosis factor- $\alpha$; TRADD, TNF receptor-associated death domain; TRAF2 TNF receptor-associated factor 2; RIP, receptor interacting protein; FADD Fasassociated death domain; JNK, c-jun amino terminal kinases; NIK, $\mathrm{NF}-\kappa \mathrm{B}$-inducing kinases; $I_{\kappa} \mathrm{B}$, inhibitor of NF- $\kappa \mathrm{B}$; MAPKs, MAP kinases; Erk1/2, extracellular regulated kinases; SAPKs, stress activated protein kinases; SZ, sulfasalazine; GADD, growth arrest and DNA damage; ROI, reactive oxygen intermediates; Mn-SOD, Mn-superoxide dismutase.

\section{Introduction}

Tumor necrosis factor- $\alpha$ (TNF- $\alpha$ ) is an inflammatory cytokine that elicits a wide range of biological responses, apoptosis being one of them. ${ }^{1,2}$ These responses occur after TNF- $\alpha$ induced trimerization of cell surface receptors p55 and p75. Although most of the biological activities of TNF- $\alpha$ appear to be transduced by $\mathrm{p} 55$, many can also be mediated by $\mathrm{p} 75,{ }^{2,3}$ although this receptor is a poorer inductor of apoptosis.

TNF- $\alpha$-induced assembling of the TNF receptor recruits other proteins, ${ }^{4,5}$ including the TNF receptor-associated death domain (TRADD), the TNF receptor-associated factor 2 (TRAF2) and the receptor-interacting protein (RIP) to p55 cytoplasmic death domain. $^{6-8}$ TRADD acts as an adapter that recruits the downstream transducers Fas-associated death domain-containing protein (FADD) and activates the apoptotic caspase 8 . In turn, TRAF2 has been implicated in the activation of two distinct pathways that leads to: the activation of AP-1 via the c-Jun amino terminal kinases (JNKs) and, together with RIP, NF- $\kappa$ B activation, via the NF- $\kappa$ B-inducing kinase (NIK).., 10

The cellular resistance to TNF- $\alpha$ has been attributed to a molecular mechanism by which TNF- $\alpha$ exerts on the target cell two different signals. One of them is the activation of caspases that leads to cell death, while the other, that requires the novo synthesis of proteins, involves a protective pathway where $\mathrm{NF}-\kappa \mathrm{B}$ regulated anti-apoptotic genes such as c-IAP1, c-IAP2, TRAF1 and TRAF2 are induced. ${ }^{9,11-17}$ The induction of these protective genes could be the reason that explains why most cells carrying p55, that are resistant become sensitized to TNF- $\alpha$-induced death with protein or RNA synthesis inhibitors, such as cycloheximide or actinomycin D. ${ }^{18}$ These observations are in agreement with other experiments showing that cells naturally resistant to $\mathrm{TNF}-\alpha$, transfected with an expression vector for the inhibitor of $\mathrm{NF}-\kappa \mathrm{B}\left(\mathrm{I}_{\kappa} \mathrm{B}\right)$, become sensitized and undergo apoptosis. ${ }^{14,17}$

Although most evidences support an anti-apoptotic role for $\mathrm{NF}-\kappa \mathrm{B},{ }^{11-17} \mathrm{p} 53$ and $\mathrm{c}-m y c$, are target genes of this transcription factor, both of which may act as proapoptotic. $^{19,20}$ Interestingly, NF- $\kappa$ B can either induce or repress apoptosis in $\mathrm{CD}^{+} \mathrm{CD}^{+}$thymocytes, depending upon the nature of the activator. ${ }^{21}$ In addition, its role in apoptosis may be dependent of the cell type, probably due to cross talk with other signals. The precise molecular mechanisms that determine the switch from an anti- to a pro-apoptotic role have not been clearly defined. A similar observation can be applied to AP-1, as some authors have reported no effect of AP-1 activation on TNF- $\alpha$-induced cell death, ${ }^{9}$ while others give to AP-1 activation a cell typespecific anti-apoptotic role. $^{11}$

The MAP kinases (MAPKs) were originally described as proteins activated by mitogens. Lately the family of MAPKs has expanded and a variety of stimuli, including non- 
mitogenic ones, have been reported as MAPKs activators. Three major MAPK families have been discovered. Erk1/2, which responds mostly to signals that trigger cell proliferation; ${ }^{22}$ JNK, which leads to AP-1 activation, through the phosphorylation of C-Jun; and ATF-2 transcription factors $^{23-25}$ and the p38 family. ${ }^{26,27}$ Four isoforms of p38 have been identified: $\mathrm{p} 38 \alpha$ (or simply $\mathrm{p} 38$ ), $\mathrm{p} 38 \beta, \mathrm{p} 38 \gamma$ (ERK6) and $\mathrm{p} 38 \delta .^{27}$

Although most reports link MAPKs to nuclear signaling, it seems clear that all of them phosphorylate both nuclear and cytoplasmic targets. The JNKs and p38s are activated by most environmental stresses (hence the name SAPKs for Stress Activated Protein Kinases) such as hyperosmolarity $^{28,29}$ and some of them can also be activated by cytokines and TNF- $\alpha^{9,26-30}$ All these kinases play critical roles as components of the signal transduction pathways that control cell differentiation, the cell cycle, and cell death. ${ }^{26-32}$ As observed with the transcription factors NF$\kappa \mathrm{B}$ and $\mathrm{AP}-1$, the role of MAP kinases in apoptosis is equally controversial. While there is a tendency to link Erk1/ 2 with cell growth and the SAPKs with the onset of apoptosis, both pro- and anti-apoptotic roles have been attributed to the members of the MAPK family. ${ }^{27,32}$

Accordingly, in this work, we analyzed the activity of these kinases as well as the role of NF- $\kappa \mathrm{B}$ activation on sensitivity to TNF- $\alpha$-induced-cell death in HeLa cells, which are naturally resistant to this cytokine. We found that osmotic stress induces a two-phase NF- $\kappa$ B activity, involving a late induction of this activity, while the early $\mathrm{NF}-\kappa \mathrm{B}$ activity induced by TNF- $\alpha$ is inhibited. Regardless of triggering a late anti-apoptotic signal, it sensitizes them to TNF- $\alpha$-induced apoptosis by a mechanism that might involve the activation of several kinases and inhibition of the anti-apoptotic gene bcl-2.

\section{Results}

\section{Stress by hyperosmolarity sensitizes HeLa cells to TNF- $\alpha$-induced apoptosis}

It was previously shown that cells naturally resistant to TNF$\alpha$-induced cell death become sensitive upon previous treatment with inhibitors of de novo protein synthesis, either at the transcriptional or translational level, as cycloheximide or actinomycin $D^{16}$ as shown in Figure $1 A$. Those chemicals are well known for their inhibitory actions, but they induce as well a variety of biochemical changes in the cell, including an increase in the enzymatic activity of some stress activated protein kinases or SAPKs. In order to analyze if additional pathways, not related to an inhibition of de novo synthesis or NF- $\kappa \mathrm{B}$ suppression could be involved on TNF- $\alpha$-induced apoptosis we investigated the role of osmotic stress. For this purpose, HeLa cells where stimulated with TNF- $\alpha$ at different doses and $100 \mathrm{mM}$ of $\mathrm{NaCl}$ for different periods of time and then cell survival was determined (Figure 1A, B, C). Although the treatment with $\mathrm{NaCl}$ alone has no effect on cell survival, it sensitizes cells to the apoptotic effect of TNF- $\alpha$ in a dose-dependent fashion (Figure 1A). Similar results were obtained with sorbitol $300 \mathrm{mM}$ plus TNF- $\alpha$ (data not shown).
TNF- $\alpha$ may induce cell death by two different pathways, depending of the target cell, such as necrosis or apoptosis. The integrity of the cellular membrane was not loss by stimulation with high doses of $\mathrm{TNF}-\alpha$ plus $\mathrm{NaCl}$, as we determined by acridine orange staining (Figure 1C). In addition, the typical internucleosomal DNA fragmentation by this treatment is shown (Figure 1C).

In some models where TNF- $\alpha$ induces apoptosis, it triggers caspase 8 activation and $\mathrm{Bcl}-2$ has a poor protective effect. $^{33}$ In addition, there are enough evidences that support an anti-apoptotic role for Bcl-2 in the pathways that involve caspase 9 activation by mitochondrial products, like cytochrome $c .^{34,35}$ In order to determine whether this pathway may be involved in this model of osmotic stress sensitization to TNF- $\alpha$-induced cell death, we analyzed the levels of Bcl-2 and Bax in HeLa cells under different treatments. As shown in Figure $2 \mathrm{~A}, \mathrm{Bcl}-2$ was significantly inhibited by treatment with $\mathrm{NaCl}$ plus TNF- $\alpha$, while the same dose of $\mathrm{NaCl}$ or TNF- $\alpha$ alone had not effect. In addition, the levels of the pro-apoptotic protein Bax, were not affected by any treatment (Figure 2B). As these results may be indicating the participation of the mitochondrial pathway in the cell death induced by $\mathrm{NaCl}$ plus TNF- $\alpha$, we then analyzed the activity of caspase 9. Given that activation of caspases is associated with the proteolitic processing of this enzime, we examined its cleavage by Western blot. Figure $2 \mathrm{~B}$ shows a slow increase of the cleavage product of $37 \mathrm{kDa}$ and a reduced amount of not cleaved substrate at $6 \mathrm{~h}$ after $\mathrm{NaCl}$ plus TNF- $\alpha$ treatment. In view that TNF- $\alpha$ may induce apoptosis through the activation of caspase 8 we also analyzed the activation of this caspase. As shown in Figure $2 \mathrm{~B}$, there is not difference on the levels of the procaspase 8 between the different treatments. Similar results were obtained for both caspases at $3 \mathrm{~h}$ and $12 \mathrm{~h}$ post treatment. The absence of caspase 8 activity probably points out that caspase 9 activation occurs in a pathway that is independent of caspase 8. These data, may suggest that hyperosmolality sensitizes the naturally resistant cells to TNF- $\alpha$ induced cell death in an apoptotic way that involves a mitochondrial pathway.

\section{Hyperosmolarity and addition of TNF- $\alpha$ activate several kinases}

There are several evidences that indicate the participation of MAPKs in the control of cell cycle and survival. ${ }^{25-30}$ In addition, it is well known that stress and TNF- $\alpha$ addition activate several of these kinases. $9,10,26-29,32$

In order to determine if a particularly different pattern of MAPK induction by a simultaneous treatment with $\mathrm{NaCl}$ plus TNF- $\alpha$ could be related to the induction of apoptosis, we performed kinase assays. We measured the levels of JNK, p38 and ERK6 activity on cell lysates from cultures stimulated with $\mathrm{NaCl}, \mathrm{TNF}-\alpha$ and $\mathrm{NaCl}$ plus TNF- $\alpha$ as indicated. As expected, the treatment with $\mathrm{NaCl}$ alone produced a stimulation of all the three kinases (Figure 3). In agreement with previous works, TNF- $\alpha$-induced not only JNK and p38, 9,10,31 but also ERK6 (Figure 3). The 


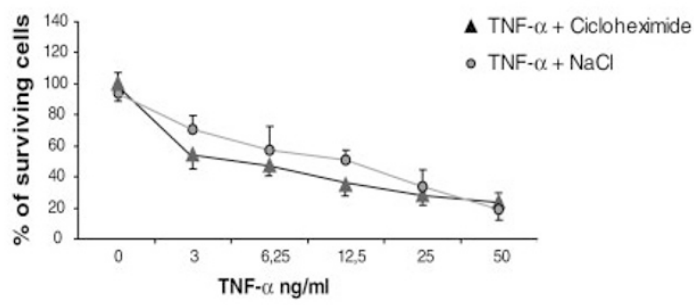

B

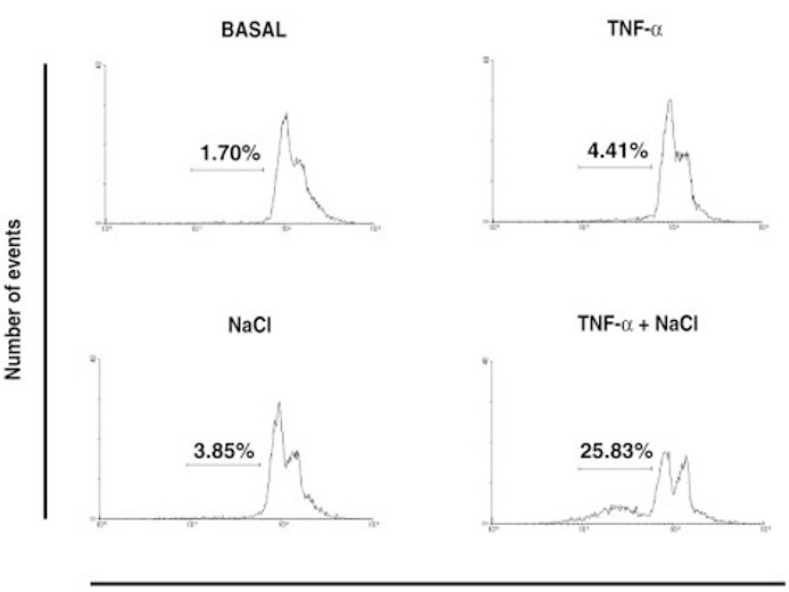

C

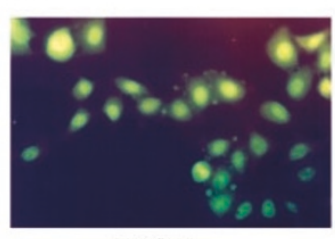

BASAL

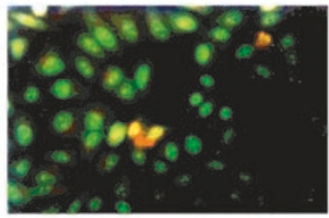

TNF- $\alpha$

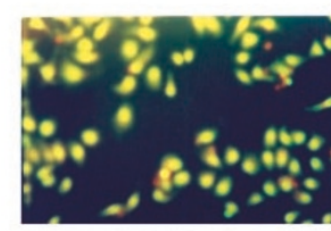

$\mathrm{NaCl}$

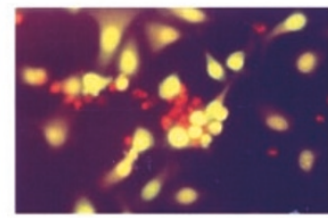

TNF- $\alpha+\mathrm{NaCl}$

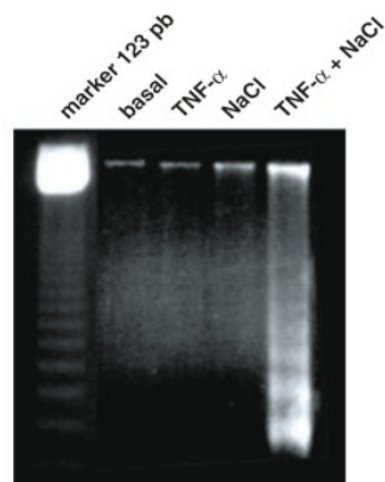

Figure $1 \mathrm{NaCl}$ sensitizes HeLa cells to TNF- $\alpha$-induced cell death. (A) Cells were treated with TNF- $\alpha$ alone or in the presence of $0.5 \mu \mathrm{g} / \mathrm{ml}$ cycloheximide or $100 \mathrm{mM}$ $\mathrm{NaCl}$ as indicated by $18 \mathrm{~h}$. Absorbance of stained surviving cells was determined at $570 \mathrm{~nm}$. Each value corresponds to the average of three wells \pm S.D., where the percentage of surviving cells was determined respect to the basal absorbance $(0.531 \pm 0.095)$. The treatment with $\mathrm{NaCl}$ or TNF- $\alpha$ ( $50 \mathrm{ng} / \mathrm{ml})$ alone have no effect on the cell number: absorbance $0.478 \pm 0.075$ and $0.504 \pm 0.060$ respectively. (B) HeLa cells were treated with $10 \mathrm{ng} / \mathrm{ml} \mathrm{TNF- \alpha ,100} \mathrm{mM} \mathrm{NaCl}$, or both. After $12 \mathrm{~h}$ of treatment cells were harvested, nuclei were stained with propidium iodide and analyzed by flow cytometry. The number above the marker in the FACS histogram represents the percentage of sub-diploid particles. (C) HeLa cells were treated with $100 \mathrm{mM} \mathrm{NaCl}, 10 \mathrm{ng} / \mathrm{ml} \mathrm{TNF}$ - $\alpha$, or both for $18 \mathrm{~h}$. Cells were stained with ethidium bromide and acridine orange. Apoptotic cells (red stained) show condensation respect to the green viable cells. The treatment with $\mathrm{NaCl}$ did not produce any change in the morphology of the cells, being large green cells, similar to the treatment with TNF- $\alpha$ or basal conditions. DNA laddering was visualized in an agarose gel electrophoresis stained with ethidium bromide. Similar results were obtained from three independent experiments

treatment with $\mathrm{NaCl}$ plus $\mathrm{TNF}-\alpha$, both in a dose whose combination induces apoptosis (Figure 1B), caused a significant increase of the three kinase activities if compared with each one of these stimulus alone (Figure 3). The observed changes on kinase ativities was not due to an increase on the levels of kinase synthesis by the treatment with $\mathrm{NaCl}, \mathrm{TNF}-\alpha$ or both simultaneously, as was confirmed by Western blots for the three kinases (Figure 3, lower panel).

These results indicate that nevertheless, being $\mathrm{NaCl}$ and TNF- $\alpha$ two types of stimulus, rely different concerning their biological role, receptors and transduction signals, yet both of them may activate at least the same three kinases. In addition, although each one of these stimuli is unable to induce apoptosis, the target cell interprets the simultaneous stimulation as a death signal. According with our results, this death signal probably correlates with a high increase or a new balance of kinase activities where p38, ERK6 and JNK are hyper-activated.

\section{Osmotic stress and TNF- $\alpha$ induce the activation of NF- $\kappa$ B}

It was previously shown that several stress signals activate the $\mathrm{NF}-\kappa \mathrm{B}$ pathway, and different kinases, including p38 kinase, have been involved in the control of its activity. ${ }^{30,36}$ In addition, there are strong evidences that support an antiapoptotic role for this transcription factor. ${ }^{11-15}$ Since in our experimental conditions, the simultaneous stimulation with two non-apoptotic signals, results in cell death, we analyzed the activity of NF- $\kappa \mathrm{B}$ under osmotic stress, TNF- $\alpha$ and the simultaneous treatment with both stimuli. Transactivation was determined at $12 \mathrm{~h}$, being that the time that cell death may be detected by microscopy and flow cytometry and earlier, at $6 \mathrm{~h}$ post stimulation, when cells look viable. Figure 4A shows that at $12 \mathrm{~h}$, in both, the osmotic stress or, as expected, TNF- $\alpha$ treatment, the transcriptional activity of NF- $\kappa \mathrm{B}$ is significantly increased with respect to the basal levels. In addition, even as the simultaneous treatment with both stimuli produces an 
A
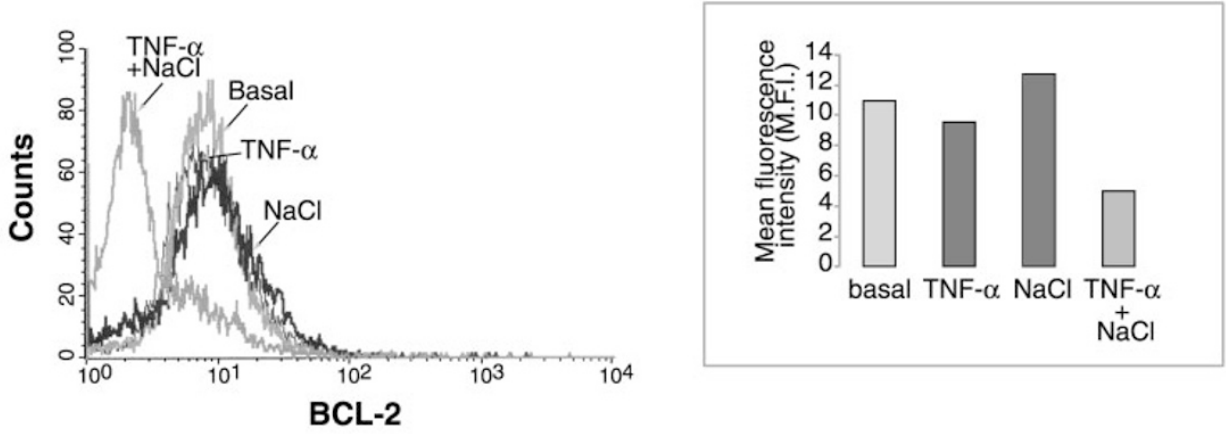

B

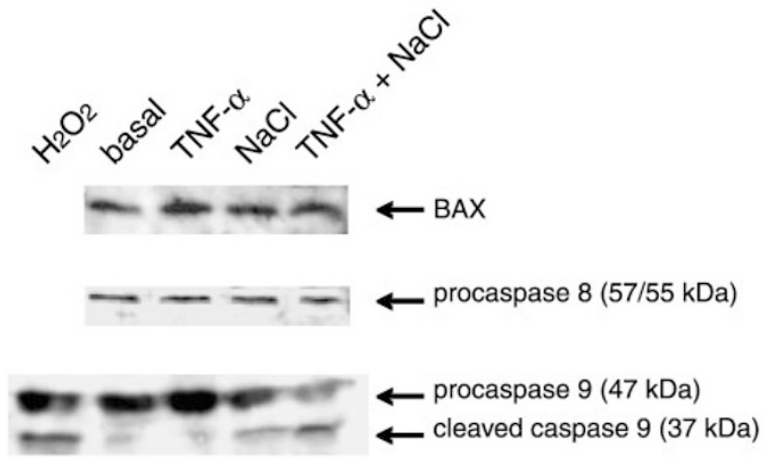

Figure 2 Analysis of caspases and expression of pro- and anti-apoptotic genes. (A) HeLa cells were treated as in $1 \mathrm{C}$ and cells were permeabilized, incubated with anti-Bcl-2 (Santa Cruz) and labeled with anti-mouse IgG-FITC. Cells were analyzed by flow cytometry. (B) HeLa cells were stimulated by $6 \mathrm{~h}$, and the specific proteins and cleavage products were detected by Western blot using specific antibodies (Santa Cruz). Similar results were obtained for caspase 8 and 9 at 3 and $12 \mathrm{~h}$. As a positive control for caspase 9 activation, cells were stimulated by $4 \mathrm{~h}$ with $0.2 \% \mathrm{H}_{2} \mathrm{O}_{2}$

apoptotic signal, it induces NF- $\kappa \mathrm{B}$ activity and there is not a synergism between both signals.

Early, at $6 \mathrm{~h}$ post stimulation the pattern of stimulation looks different. The transcriptional activity of $N F-\kappa B$ is significantly increased under TNF- $\alpha$ treatment, but surprisingly $\mathrm{NaCl}$ has a poor stimulatory effect respect to the basal levels. In addition, the simultaneous treatment with both stimuli produces a significant inhibition on NF- $\kappa \mathrm{B}$ activity respect to the cultures stimulated with TNF- $\alpha$ alone (Figure 4C).

Although both stimuli produce an increase on $\mathrm{NF}-\kappa \mathrm{B}$ activity at one late phase in the route to apoptosis these results, clearly demonstrate that each one of these inductors have a different kinetics, that probably involves a specific particular cascade leading to NF- $\kappa \mathrm{B}$ activation. Furthermore, some additional inhibitory signal for $\mathrm{NF}-\kappa \mathrm{B}$ activation is triggered early by hyperosmotic stress.

It was previously reported that p38 activity is required for the NF- $\kappa \mathrm{B}$ activity induced by TNF- $\alpha .^{30}$ In order to analyze the requirement of this kinase for each one of the routes to $\mathrm{NF}-\kappa \mathrm{B}$ activation used by TNF- $\alpha, \mathrm{NaCl}$ or both simultaneously, we analyzed the effect of the specific p38 inhibitor SB203580. Our results indicate that the addition of the specific p38 inhibitor, in a dose that is clearly effective
(Figure 4B) has an inhibitory effect on NF- $\kappa \mathrm{B}$ transactivation induced by every treatment (Figure 4A,C). These results demonstrate that some different pathways that lead to the increase on NF- $\kappa \mathrm{B}$ activation are used by osmotic stress, TNF- $\alpha$ or both, simultaneously. However, this kinase plays an important role on regulating NF- $\kappa \mathrm{B}$ transactivation, which is independent of the type of stimuli or its kinetics.

\section{Inhibition of NF- $\kappa$ B or p38 increases the $\mathrm{NaCl}$ sensitization to TNF- $\alpha$-induced cell death}

According to our results, NF- $\kappa \mathrm{B}$ is activated by osmotic stress plus TNF- $\alpha$ through a pathway that involves at least p38. Therefore, we wanted to determine the role of NF- $\kappa \mathrm{B}$ and the p38 pathway in this model of apoptosis. For this purpose, the cells were stimulated with the specific inhibitor of $\mathrm{NF}-\kappa \mathrm{B}$, sulfasalazine, in a dose that is not cytotoxic (Figure $5 \mathrm{~A}$ ) and inhibits NF- $\kappa$ B activity (Figure $5 \mathrm{~B}$ ) and then stimulated with $\mathrm{NaCl} 100 \mathrm{mM}$ plus TNF- $\alpha$. Flow cytometry measurements were performed and as shown in Figure 5A, the addition of sulfasalazine, at a dose that has not basal effect, increases the cell death induced by the simultaneous treatment with $\mathrm{NaCl}$ plus TNF- $\alpha$ with respect to the cultures with the same stimulation, but without the inhibitor. These results clearly 

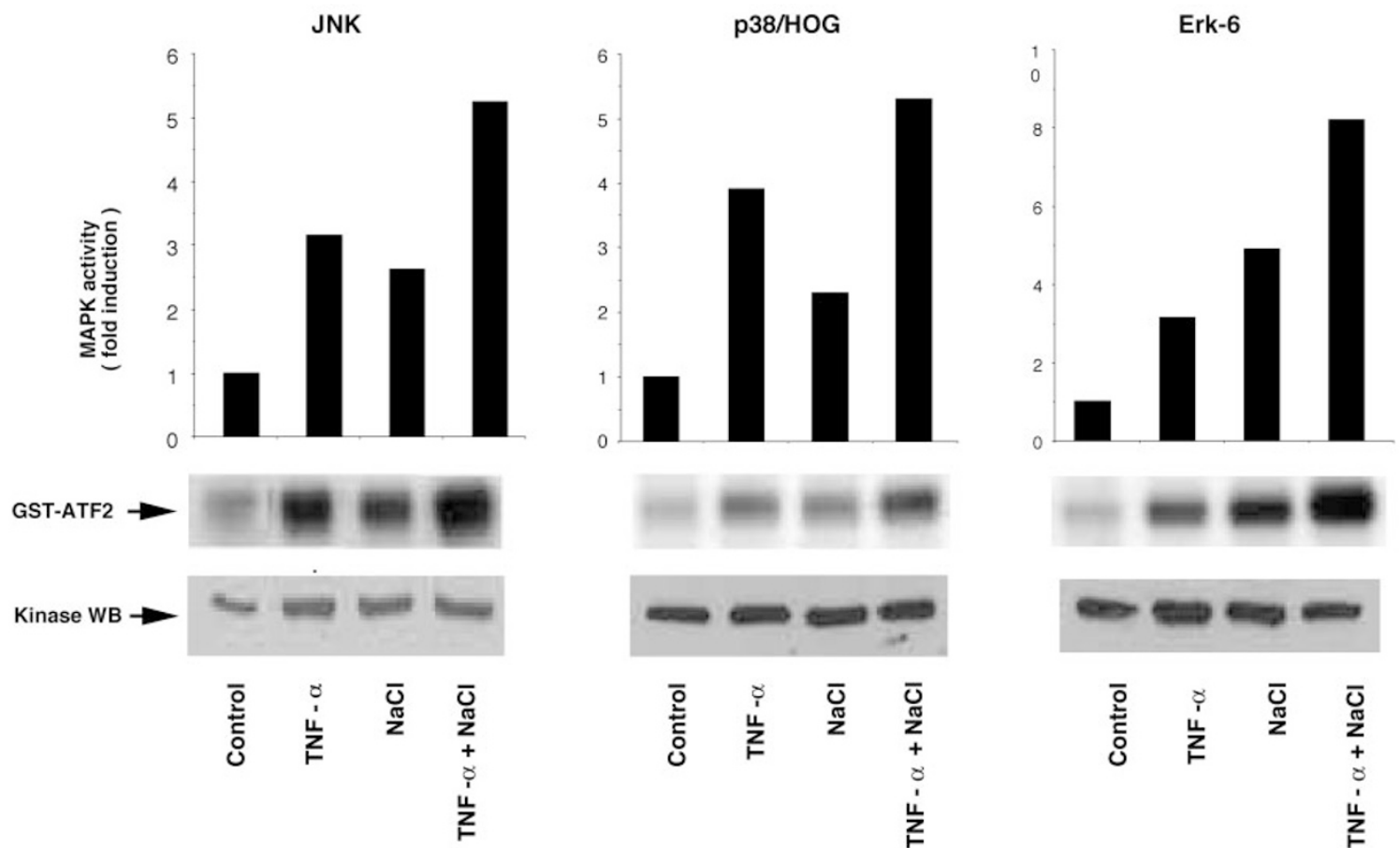

Figure 3 Activation of stress activated protein kinases in HeLa cells. HeLa cells were stimulated with $10 \mathrm{ng} / \mathrm{ml} \mathrm{TNF}-\alpha, 100 \mathrm{mM} \mathrm{NaCl}$ or both during $20 \mathrm{~min}$. Then the cells were harvested and the endogenous kinases were inmunoprecipitated with the aid of a specific antibody for JNK or p38. In the case of Erk-6, a plasmid expressing the corresponding CDNA expressed as a fusion protein with the HA epitope was transfected. The activity was quantified and presented as fold induction relative to the unstimulated controls. The panel in the middle shows the bands corresponding to phosphorylated substrates and corresponds to a representative experiment. The Western blots in the lower panel show the amount of total kinase present in the assays. Similar results were obtained in three independent experiments

demonstrate that $\mathrm{NF}-\kappa \mathrm{B}$ is a protective signal, which is induced later under apoptotic conditions such as osmotic stress plus TNF- $\alpha$, but is not sufficient to avoid cell death.

We demonstrate in this work that inhibition of p38 activity down-regulates $N F-\kappa B$ transactivation induced by $\mathrm{NaCl}$, TNF- $\alpha$ or both simultaneously (Figure 4A, C). Therefore we wanted to analyze the role of this kinase in the pathway to apoptosis. The inhibition of p38 by treatment with SB203580 strongly enhances the osmotic stress sensitization to TNF- $\alpha$-induced cell death (Figure $5 A$ ). In order to determine if the increase on $\mathrm{NaCl}$ plus $\mathrm{TNF}-\alpha$-induced cell death by blockade of p38 activity is a consequence of a decreased $\mathrm{NF}-\kappa \mathrm{B}$ transactivation, we analyzed the effect of Rel-A. The cells were transfected with an expression vector for Rel-A in a dose that clearly induces NF- $\kappa \mathrm{B}$ activity (Figure 5B) or the empty vector as a control, and then stimulated as shown in Figure 5A. From our results, it is evident that although Rel-A totally reverts the increase on sub-diploid cells, due to the inhibitory effect of sulfasalazine on the activation of $\mathrm{NF}-\kappa \mathrm{B}$ by $\mathrm{NaCl}$ plus $\mathrm{TNF}-\alpha$, it partially reverts the increase on cell death produced by p38 inhibition. In addition, although sulfasalazine does not have a significant inhibitory effect on NF- $\kappa \mathrm{B}$ transactivation under Rel-A constitutively expressed (Figure 5B), this activity is significantly inhibited by SB203580 (Figure 5B). From these data, we conclude that p38 is a protective signal. Although we cannot exclude some additional anti-apoptotic pathway, p38 could be acting through NF- $\kappa \mathrm{B}$ activation, which is not totally dependent on the levels of available Rel-A, but probably involves some downstream signal related to NF$\kappa \mathrm{B}$ transactivation.

\section{Discussion}

Although most cells are resistant to TNF- $\alpha$-induced cell death, there are several ways to turn them sensitive, and all of them involve the inhibition of protective NF- $\kappa$ B target genes. ${ }^{11-17}$ In this work, we report a new model of TNF- $\alpha$-induced apoptosis by sensitization with osmotic stress. In our model, an early inhibition of NF- $\kappa \mathrm{B}$ activity is involved, but also, cell death is induced in spite of the increase of the late NF- $\kappa$ B activation by these signals. Although these results could be probably suggesting that $\mathrm{NF}-\kappa \mathrm{B}$ has a pro-apoptotic role in this model, our results clearly show that blocking NF- $\kappa \mathrm{B}$ activation increases the sensitivity to apoptosis. Thus, we may conclude that in these specific conditions that lead the cells to apoptosis, a two-phase response is taking place. This transcription factor is induced in a later phase as a defensive response, but its action is not strong enough to prevent cell death, while its early inhibition by $\mathrm{NaCl}$ is probably a critical point that leads the cells to apoptosis under TNF- $\alpha$ stimulation.

The loss of cell volume is a fundamental feature of apoptosis. ${ }^{37-41}$ Under hypotonic stress cells can re-adjust their volume after transient osmotic swelling which is accomplished mainly by $\mathrm{KCl}$ efflux. ${ }^{40}$ There are enough 
A

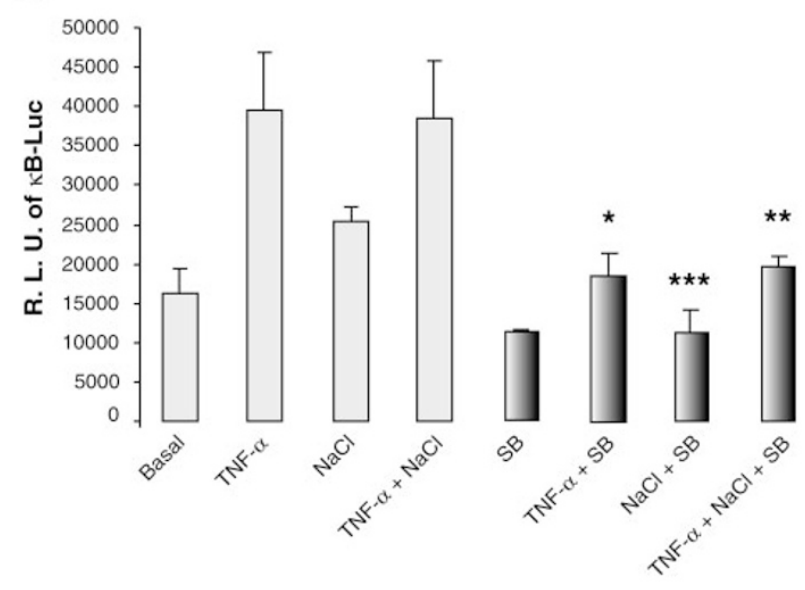

B

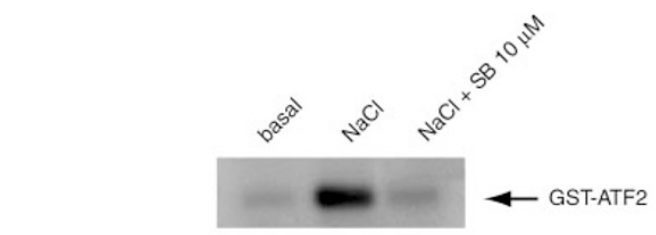

C

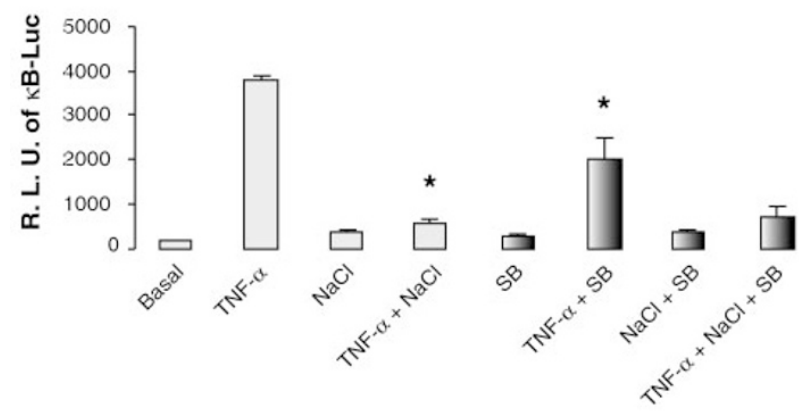

Figure 4 p38 MAP kinase has a role in the NF- $\kappa$ B activity induced by TNF- $\alpha$ and $\mathrm{NaCl}$. (A) HeLa cells were transfected with $0.5 \mu \mathrm{g} \kappa \mathrm{B}$-Luc reporter plasmid, $0.5 \mu$ of RSV- $\beta$-Gal and $2 \mu \mathrm{g}$ of empty vector, and stimulated by $12 \mathrm{~h}$ with $10 \mathrm{ng} / \mathrm{ml}$ TNF- $\alpha, 100 \mathrm{mM} \mathrm{NaCl}$ and $10 \mu \mathrm{M} \mathrm{SB} 203580$ as indicated. Relative luminescence units are the average of triplicate \pm S.D. and were normalized with the corresponding $\beta$-galactosidase values. (B) HeLa cells were treated with $100 \mathrm{mM} \mathrm{NaCl}$ in the presence or the absence of $10 \mu \mathrm{M} \mathrm{SB203580} \mathrm{for}$ $30 \mathrm{~min}$ and p38 MAPK induced phosphorylation of GST-ATF2 was assayed as described in Materials and Methods. (c) As in (A) but the cells were stimulated by $6 \mathrm{~h}$. For all conditions, at least $P<0.05$ (ANOVA with Fisher's test). ${ }^{*}$ Respect to TNF- $\alpha,{ }^{* *}$ respect to TNF- $\alpha+\mathrm{NaCl},{ }^{* *}$ respect to $\mathrm{NaCl}$

evidences supporting the idea that the efflux of ions associated with cell shrinkage, particularly $\mathrm{K}^{+}$, plays a critical role in the cell death program ${ }^{37}$ and is a necessary event for DNA degradation. ${ }^{41}$ In addition, it was previously shown that ions in high concentration, as $150 \mathrm{mM}$ may act as repressors of apoptosis in living cells. ${ }^{41}$ In this work, although TNF- $\alpha$, like other inducers of apoptosis may cause a reduction on cell volume and the loss of ions, ${ }^{40}$ this should be prevented under hyperosmotic condition such as
A
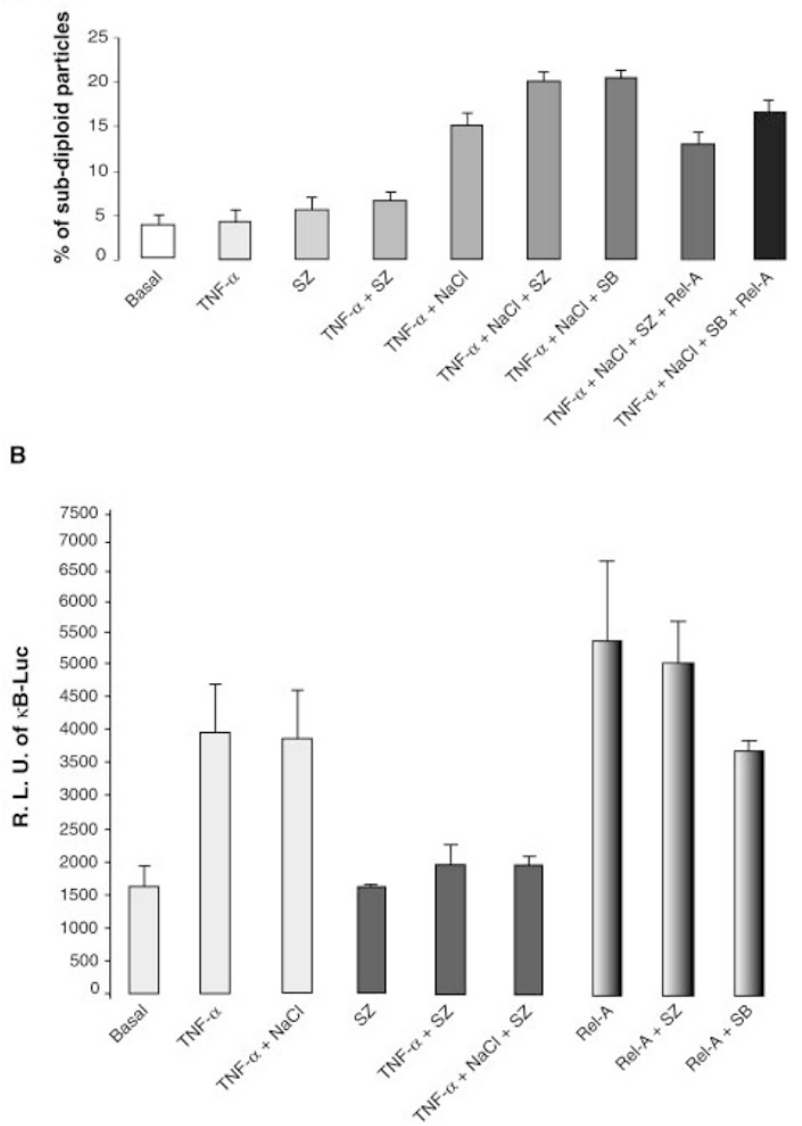

Figure 5 Effect of the p38 MAPK inhibitor SB203580 and sulfasalazine in apoptosis induced by TNF- $\alpha$ in cells sensitized with $\mathrm{NaCl}$. (A) HeLa cells were transfected by using lipofectamine plus (GIBCO BRL) with $2 \mu \mathrm{g}$ of CMV-RelA or $2 \mu \mathrm{g}$ of empty vector and $0.5 \mu \mathrm{g} \mathrm{RSV}-\beta$-Gal, and after $48 \mathrm{~h}$ of culture without lipofectamine, they were treated with $100 \mathrm{mM} \mathrm{NaCl}$ and $10 \mathrm{ng} / \mathrm{ml} \mathrm{TNF}-\alpha$ in the presence or not of $10 \mu \mathrm{M} \mathrm{SB203580}$ or $200 \mu \mathrm{M}$ sulfasalazine (SZ), as indicated. After $12 \mathrm{~h}$ of treatment, cells were harvested, stained with propidium iodide, and analysed by flow cytometry. The transfection eficiency $(70 \%)$ was determined by X-gal staining. The diagram bars corresponds to the average \pm S.D. of triplicates. (B) In order to confirm that $200 \mu \mathrm{M}$ of sulfasalazine is an effective dose for inhibition of NF- $\kappa$ B activity, HeLa cells were co-transfected with $0.5 \mu \mathrm{g}$ (B-Luc reporter plasmid, $2 \mu \mathrm{g}$ of CMV-RelA or empty vector, and $0.5 \mu \mathrm{g} \mathrm{RSV}-\beta$-Gal for normalization. Cells were stimulated with $10 \mathrm{ng} / \mathrm{ml} \mathrm{TNF}-\alpha$ in the presence or not of $200 \mu \mathrm{M}$ of sulfasalazine by $24 \mathrm{~h}$. The diagram bars correspond to the average of triplicate wells \pm S.D. Similar results were obtained in three independent experiments

$100 \mathrm{mM}$ of $\mathrm{NaCl}$. In our work, both high $100 \mathrm{mM} \mathrm{NaCl}$ and $300 \mathrm{mM}$ sorbitol sensitize the naturally resistant HeLa cells to TNF- $\alpha$-induced cell death. Taken together all these observations and our own results, we can hypothesize that in the model of hyperosmotic sensitization to TNF- $\alpha$ induced cell death, the loss of intracellular ions may be not a necessary event.

There are evidence that hyperosmolarity $(150 \mathrm{mM} \mathrm{NaCl})$ causes growth arrest of murine kidney cells, which involves the induction of the growth arrest and DNA damageinducible (GADD) gene products. ${ }^{42}$ In this model, ERK1/2 and p38 are activated, but while p38 stimulates GADD induction, ERK1/2 is inhibitory. It was previously shown that 
TNF- $\alpha$, as well as hyperosmotic stress, induce the activity of several kinases. $9,10,26,30,32$ In this regard, it has been proposed that the balance between the intracellular levels of ceramide and sphingosine-1-phosphate and their regulatory effects on JNK and ERK pathway respectively, could be determining the fate of the cell. ${ }^{32}$

According with this idea, a combination of both stimuli, such as TNF- $\alpha$ plus $\mathrm{NaCl}$, could be producing a new balance in the levels of kinase activity probably involved in cell death. In our study all of the kinases induced by each one of the stimuli show a similar pattern of activation being maximal with the combination of the osmotic stress and TNF- $\alpha$ treatment. Although the increased activity of some of these pathways could be playing a role in the control of TNF- $\alpha$-induced death/survival response, we cannot discard that additional signaling mechanisms, not related to these cascades could be involved in the switch. Previous reports show the participation of p38 on NF- $\kappa$ B activation, ${ }^{30,43}$ but the precise mechanism by which this occurs is not so clear at present and might be dependent on the cell context. In addition, some evidence supports the requirement of p38 activity on TNF- $\alpha$-induced NF- $\kappa$ B transactivation. ${ }^{30}$ Moreover, according to our data, the requirement of this kinase seems to be critical for NF- $\kappa \mathrm{B}$ activation and independent of the kinetics of each one of the stimulus.

In other way, we showed that inhibition of p38 kinase significantly increases the cell death induced by osmotic stress and TNF- $\alpha$. Thus, in the new balance of kinases induced by osmotic stress and $T N F-\alpha$, p38 plays a protective role that is not strong enough to prevent apoptosis. Interestingly, according to our results, the effect of p38 inhibition cannot be totally reverted by the overexpression of Rel-A. This could be compatible with the inhibitory effect of SB203580 on NF- $\kappa$ B transactivation, even under a constitutive Rel-A over-expression (Figure $5 B)$. These results could probably indicate that the antiapoptotic role of p38 is mediated by $N F-\kappa B$, but in a further step downstream of $\mathrm{I} \kappa \mathrm{B}$ proteolysis and not totally dependent of the levels of the active molecules of transcription factor. However, we should not discard that p38 plays its protective role not only by enhancing NF- $\kappa \mathrm{B}$ activity, but also, some additional protective signals, not related to this transcription factor could be triggered.

Besides the activation of caspases, it was previously reported that the cytotoxic effects of TNF- $\alpha$ are due in part to its ability to induce the generation of reactive oxygen intermediates (ROI) and oxidative damage, ${ }^{44,45}$ that would be the principal pathway for death in cells naturally sensitive to TNF- $\alpha$. Overexpression of $\mathrm{Mn}$-superoxide dismutase (Mn-SOD) has been shown to be a major pathway by which cells can protect themselves against cytotoxic effects of TNF- $\alpha{ }^{45}$ Mitochondria are the major source of these species, which are increased after loss of the electrochemical gradient across the inner membrane. ${ }^{45}$ According with this knowledge, it has been suggested that in $\mathrm{TNF}-\alpha$ resistant cell lines, mitochondrial damage is prevented by an increase in Mn-SOD. ${ }^{44}$ In this regard, perhaps, any signal that impairs the integrity of the inner mitochondrial membrane, or inhibits either, anti-oxidants or the mitochondrial protective signals, like $\mathrm{Bcl}-2$ could, probably sensitize cells to TNF- $\alpha$-induced cell death. How hyperosmolarity could be affecting some of these mechanisms remains to be determined.

It is well known that TNF- $\alpha$ activates caspase 8 but there are signals that directly affect the mitochondria which leads to caspase 9 activation without the requirement of caspase 8 activity $^{34,35}$ and $\mathrm{Bcl}-2$ has a regulatory role on preventing this effect. ${ }^{35}$ According to our results, the levels of Bcl-2 are inhibited by the apoptotic signal elicited by osmotic stress plus TNF- $\alpha$, while Bax levels are nor affected. In addition, caspase 9 seems to be activated by all the different stimulus, and a slow increase is observed under the apoptotic treatment of $\mathrm{NaCl}$ plus $\mathrm{TNF}-\alpha$. In these conditions, a diminished ratio of $\mathrm{Bcl}-2 / \mathrm{Bax}$ as occurs under $\mathrm{NaCl}$ plus TNF- $\alpha$ treatment, suggest that in this particular model the mitochondrial pathway could play an important role on signaling for cell death, where inhibition of the protective $\mathrm{Bcl}-2$, plus the early activation of $\mathrm{NF}-\kappa \mathrm{B}$ could be critical.

Finally, we show that a not apoptotic stimulus as the hyperosmotic stress may sensitize to TNF- $\alpha$-induced cell death in cells that are naturally resistant to this cytokine, which is the case for most cells in the organism. Since almost all the tissues, in normal and inflammatory response are exposed to both TNF- $\alpha$ and changes in the osmolarity of physiological fluids, these results could be an important contribution to the knowledge of some physiological or pathological conditions involving hypertension, high levels of inflammatory cytokines in plasma and tissue damage.

\section{Materials and methods}

\section{Cells and reagents}

Human cervix carcinoma HeLa cells were grown in Dulbecco's modified Eagle's medium (DMEM) (Gibco Laboratories, Grand Island, NY, USA) supplemented with $10 \%$ fetal calf serum (FCS) (Gibco, Paisley, UK), penicillin (100 units $/ \mathrm{ml}$ ) and streptomycin (100 mg/ml). Cells were maintained at $37^{\circ} \mathrm{C}$ in a humidified atmosphere with $5 \%$ $\mathrm{CO}_{2}$. Unless stated, reagents were obtained from Sigma Chemical Co (St. Louis, MO, USA), Pharmacia (Uppsala, Sweden) or Calbiochem.

\section{Determination of NF- $\kappa$ B activity}

The NF- $\kappa$ B activity determination was performed as previously described. ${ }^{15}$ Briefly, cells were cultured in 6 -well plates at a density of $2.5 \times 10^{4}$ cells/well in DMEM without serum or antibiotics and transiently transfected with a total of $3 \mu \mathrm{g}$ of DNA (including $0.5 \mu \mathrm{g}$ of $\kappa \mathrm{B}$-Luc reporter $0.5 \mu \mathrm{g}$ of constitutive RSV- $\beta$-Gal control vector and $2 \mu \mathrm{g}$ of CMV-Rel-A or empty vector) using lipofectamine or lipofectamine plus (Gibco BRL). After $5 \mathrm{~h}$ (or $3 \mathrm{~h}$ when using lipofectamine plus), transfection medium was replaced by DMEM $10 \%$ serum. Cells were stimulated with human TNF- $\alpha$ (Calbiochem) at a concentration of $10 \mathrm{ng} / \mathrm{ml}, \mathrm{NaCl} 100 \mathrm{mM}$, the NF- $\kappa \mathrm{B}$ inhibitor sulfasalazine (SZ) $200 \mu \mathrm{M}$ which inhibits NF- $\kappa$ B activation ${ }^{15,47}$ and $10 \mu \mathrm{M}$ p38 inhibitor SB203580, as indicated, and cultured for $6 \mathrm{~h}$ or $12 \mathrm{~h}$ prior harvesting. Cellular extracts for luciferase and $\beta$ galactosidase assays were prepared, and assays were performed using the appropriate substrates following the manufacturer's protocols (Promega corp.). For experiments of surviving, cells transfected with the expression vector for Rel-A or empty vector, by 
using lipofectamine plus were replated after $24 \mathrm{~h}$ and stimulated $24 \mathrm{~h}$ later.

\section{Kinase assays}

Kinase assays were performed as previously reported. ${ }^{24}$ Briefly, HeLa cells were transfected with $0.5 \mu \mathrm{g}$ of pCDNA-HA-Erk- 6 by the lipofectamine technique. Total amount of plasmid DNA was adjusted to $3 \mu \mathrm{g}$ per well using empty vector. Two days later transfected cells were kept for $2 \mathrm{~h}$ in serum-free medium. Then, cells were left untreated or stimulated with TNF- $\alpha 10 \mathrm{ng} / \mathrm{ml}$, with $\mathrm{NaCl} 100 \mathrm{mM}$ or both for $20 \mathrm{~min}$, washed with PBS, and lysed at $4^{\circ} \mathrm{C}$ in a buffer containing $25 \mathrm{mM}$ HEPES (ph 7.5), $0.3 \mathrm{M} \mathrm{NaCl}, 1.5 \mathrm{mM} \mathrm{MgCl}_{2}, 0.2 \mathrm{mM}$ EDTA, $0.5 \mathrm{mM}$ DTT, $1 \%$ Triton X-100, $0.5 \%$ sodium vanadate, $1 \mathrm{mM}$ phenilmethilsulphonilfluoride, $20 \mu \mathrm{g} / \mathrm{ml}$ leupeptin. The epitope tagged Erk-6 (or the endogenous kinases, for JNK and p38) was inmunoprecipitated from the cleared lysates by incubation with the specific antibody (Covance and Santa Cruz respectively) for $2 \mathrm{~h}$ at $4^{\circ} \mathrm{C}$. The inmunocomplex was recovered with the aid of Gamma Bind Sepharose beads (Pharmacia), washed three times with PBS containing $1 \%$ NP-40 and $2 \mathrm{mM}$ sodium vanadate, once with $100 \mathrm{mM}$ Tris $(\mathrm{pH} 7.5), 0.5 \mathrm{M} \mathrm{LiCl}$, and once with kinase reaction buffer (12.5 mM MOPS (pH 7.5), $12.5 \mathrm{mM} \beta$-glycerophosphate, $7.5 \mathrm{mM} \mathrm{MgCl} 2,0.5 \mathrm{mM}$ EGTA, $0.5 \mathrm{mM}$ sodium fluoride, $0.5 \mathrm{mM}$ sodium vanadate). The Erk- 6 kinase activity present in the inmunocomplex was determinated by resuspension in $30 \mu \mathrm{l}$ of kinase reaction buffer containing $1 \mu \mathrm{Ci}$ of $\left[\gamma^{32} \mathrm{P}\right]$ ATP per reaction and $20 \mu \mathrm{M}$ unlabeled ATP, using $1 \mu \mathrm{g}$ of GST-ATF2 fusion protein as a substrate, similarly to the protocol already described for $\mathrm{JNK}^{24}$ The same substrate was used to measure JNK or p38 kinase activity. After $30 \mathrm{~min}$ at $30^{\circ} \mathrm{C}$, reactions were terminated by addition of $10 \mu \mathrm{l}$ of $5 \times$ Laemmli buffer. Samples were heated at $95^{\circ} \mathrm{C}$ for $5 \mathrm{~min}$ and analyzed by SDS electrophoresis on $12 \%$ polyacrylamide gels. Autoradiography was performed to detect the phosphorylated products.

\section{Cytotoxicity and apoptosis assays}

Cytotoxicity was determined as previously described. ${ }^{15}$ Briefly, HeLa cells were plated at $1.5 \times 10^{3}$ cells/well in 96 -well microtiter plates and stimulated with different doses of $h-T N F-\alpha$ and $\mathrm{NaCl} 100 \mathrm{mM}$. After $18 \mathrm{~h}$, cells were fixed with $70 \%$ methanol and stained with $0.5 \%$ crystal violet. The absorbance corresponding to the stained surviving cells was determined at $570 \mathrm{~nm}$. The per cent of surviving cells was determined respect to the basal conditions (without any treatment).

In some experiments, cells at a density of $3 \times 10^{5}$ cells/well in sixwell plates, were transiently transfected with an expression vector for Rel-A or the empty vector as indicated before, and then stimulated with different doses of $\mathrm{h}-\mathrm{TNF}-\alpha$ and $\mathrm{NaCl} 100 \mathrm{mM}$, in the absence or the presence of SZ or the p38 kinase inhibitor SB203580, for $12 \mathrm{~h}$.

Cells with degraded DNA were determined by gating on those displaying sub-diploid (sub-G0/G1) DNA content. These studies were performed by propidium iodide. After the different treatments, $2 \times 10^{6}$ cells were washed twice on PBS, and incubated overnight in $50 \mu \mathrm{g} / \mathrm{ml}$ propidium iodide solution ( $0.1 \%$ sodium citrate, $0.1 \%$ Triton $\mathrm{X}-100)$ at $4{ }^{\circ} \mathrm{C}$. Samples were measured in a Cytoron Absolute (Ortho Diagnostic Systems, New Brunswick, NJ, USA). In order to determine the number of sub-diploid cells, the data were analyzed with a WinMDI 2.8 software.

Some cultures were stained with acridine orange and ethidium bromide and the morphology of death and surviving cells was observed at fluorescent microscopy. Ethidium bromide only enters into non-viable cells and stains chromatin a dark orange color. Acridine orange penetrates in viable cells and turns green when it intercalates with DNA. These experiments confirm, as previously shown ${ }^{15}$ that the cell death induced by TNF- $\alpha$ plus $\mathrm{NaCl}$ is apoptosis.

\section{DNA laddering}

The inter-nucleosomal fragmentation of DNA is a characteristic of apoptotic cells. ${ }^{11-15}$ In order to analyze this parameter in our model, each cell suspension $\left(5 \times 10^{6}\right.$ cells) was washed twice with PBS and the cell pellet was resuspended in $800 \mu$ l of lysis buffer $(0.5 \%$ Triton X100; $5 \mathrm{mM}$ Tris- $\mathrm{HCl} \mathrm{pH} \mathrm{7.5;} 20 \mathrm{mM}$ EDTA). After $30 \mathrm{~min}$ on ice, the lysate was centrifuged (14000 r.p.m.) for $10 \mathrm{~min}$ at $4^{\circ} \mathrm{C}$. The aqueous phase was precipitated with sodium acetate $30 \mathrm{mM}$ and 0.7 volumes of isopropanol. The pellet was washed with $80 \%$ ethanol, dried and resuspended in $100 \mu \mathrm{l}$ TE (10 mM Tris- $\mathrm{HCl}, 1 \mathrm{mM}$ EDTA, pH 8). Samples were treated with ribonuclease $A(0.5 \mathrm{mg} / \mathrm{ml})$ for $1 \mathrm{~h}$ at $37^{\circ} \mathrm{C}$, then a phenol-chloroform/isoamil alcohol extraction was performed and the aqueous phase was precipitated with 2 volumes of ethanol. The nucleic acid pellet was resuspended in $40 \mu \mathrm{l}$ of buffer TE, and electrophoresis was carried out in a $2 \%$ agarose gel in TBE buffer. DNA was visualized by ethidium bromide staining. A 123 bp marker (Gibco BRL, Grand Island, NY, USA) was run in parallel lanes as an indicator of molecular weight.

\section{Caspases and Bax analysis}

The activity of caspases 8 and 9 and the levels of the pro-apoptotic Bax protein were analyzed by Western blot. Briefly, HeLa cells were stimulated or not with $100 \mathrm{mM} \mathrm{NaCl}, 10 \mathrm{ng} / \mathrm{ml} \mathrm{TNF}-\alpha$ or the combination of both by $3,6,12$ and $16 \mathrm{~h}$. Then, the cultures were washed with PBS, and lysed at $4^{\circ} \mathrm{C}$ in a buffer containing $25 \mathrm{mM}$ HEPES (ph 7.5), $0.3 \mathrm{M} \mathrm{NaCl}, 1.5 \mathrm{mM} \mathrm{MgCl}_{2}, 0.2 \mathrm{mM}$ EDTA, $0.5 \mathrm{mM}$ DTT, $1 \%$ Triton $X-100,0.5 \%$ sodium vanadate, $1 \mathrm{mM}$ phenilmethilsulphonilfluoride, $20 \mu \mathrm{g} / \mathrm{ml}$ leupeptin. Cytosolic extracts were denatured in Laemmli loading buffer at $95^{\circ} \mathrm{C}$ for $5 \mathrm{~min}$ and separated in a $12 \%$ SDS-PAGE gel. The proteins were transferred to nitrocelulose membrane for immunoblotting. The membranes were incubated with the specific antibodies: a rabbit polyclonal antibody against human Casapase-8, a rabbit polyclonal antibody against Casapase- 9 and a rabbit policlonal antibody against Bax (all from Santa Cruz). Specific proteins were detected using ECL reagents.

\section{Acknowledgements}

We thank all the members of the Laboratorio de Fisiología y Biología Molecular and to the Director of the Instituto de Investigaciones Médicas A Lanari, Dr Samuel Finkielman for comments about the manuscript. We specially thank to Dr Víctor E Nahmod for helpful discussions about this work. This work has been supported by grants from the University of Buenos Aires (UBA), the Argentine National Research Council (CONICET), Agencia Nacional de Promoción Científica y Tecnológica, Ministerio de Salud and Fundación Antorchas, Argentina.

\section{References}

1. Tracey KJ and Cerami A (1993) Tumor necrosis factor, other cytokines and disease. Annu. Rev. Cell. Biol., 9: 317-343

2. Vandenabeele P, Declercg W, Beyaert R and Fiers W (1995) Two tumornecrosis factor receptors: structure and function. Trends Cell Biol. 5: 392-399

3. Tartaglia LA and Goeddel DV (1992) Two TNF receptors. Immunol. Today 13: $151-153$ 
4. Rothe M, Wong SC, Henzel W J and Goeddel DV (1994) A novel family of putative signal transducers associated with the cytoplasmic domain of the $75 \mathrm{kDa}$ tumor necrosis factor receptor. Cell 78: 681-692

5. Hsu H, Xiong J and Goeddel DV (1995) The TNF receptor-1-associated protein TRADD signals cell death and NF- $\kappa$ B activation. Cell 81: 495-504

6. Stanger BZ, Leder P, Lee TH, Kim E and Seed B (1995) RIP: a novel protein containing a death domain that interacts with Fas/APO-1 (CD95) in yeast and causes cell death. Cell 81:513-523

7. Hsu H, Shu HB, Pan MG and Goeddel DV (1996) TRADD-TRAF2 and TRADDFADD interactions define two distinct TNF receptor-1 signal transduction pathways. Cell 84: 299-308

8. Hsu H, Shu HB, Baichwal V and Goeddel DV (1996) TNF-dependent recruitment of the protein kinase RIP to the TNF receptor-1 signaling complex. Immunity 4: 387-396

9. Liu Z, Hsu H, Goeddel DV and Karin M (1996) Dissection of TNF receptor 1 effector functions: JNK activation is not linked to apoptosis while NF- $\kappa$ B activation prevents cell death. Cell $87: 565-576$

10. Wajant $H$, Henkler $F$ and Scheurich $P$ (2001) The TNF-receptor-associated factor family scaffold molecules for cytokine receptors, kinases and their regulators. Cell Signal 13: $389-400$

11. Gioacchino N, Costanzo A, Guido F, Moretti AB, Burgio VL, Agresti $C$ and Levrero M (1998) Nuclear factor $\kappa$ B-independent cytoprotective pathways originating at tumor necrosis factor receptor-associated factor 2. J. Biol. Chem. 273: $31262-31272$

12. Beg $A$ and Baltimore $D$ (1996) An essential role for NF- $\kappa B$ in preventing TNF- $\alpha-$ induced cell death. Science 274: 782-784

13. Chu Z L, McKinsey T, Liu L, Gentry JJ, Malim MH and Ballard DW (1997) Suppression of tumor necrosis factor-induced cell death by inhibitor of apoptosis C-IAP2 is under NF- $k$ B control. Proc. Natl. Acad. Sci. USA 94: 10057-10062

14. Wang CY, Mayo MW and Baldwin Jr AS (1996) TNF- $\alpha$ and cancer therapyinduced apoptosis: potentiation by inhibition of NF- $\kappa$ B. Science 274: 784-787

15. Costas M A, Muller Igaz L, Holsboer F and Arzt E (2000) Transrepression of NF$\kappa \mathrm{B}$ is not required for glucocorticoid-mediated protection of TNF- $\alpha$-induced apoptosis on fibroblasts. Biochim. Biophys. Acta 1499: 122-129

16. Wang C, Mayo MW, KornelukRG, Goeddel DV and Baldwing JrAS (1998) NF- $k B$ antiapoptosis: Induction of TRAF1 and TRAF2 and C-IAP1 and C-IAP2 to suppress caspase-8 activation. Science 281: 1680-1683

17. Van Antwerp DJ, Martin SJ, Kafri T, Green DR and Verma IM (1996) Suppression of TNF- $\alpha$-induced apoptosis by NF- $\kappa$ B. Science 274: 787-789

18. Larrick JW and Wright SC (1990) Cytotoxic mechanism of tumor necrosis factoralpha. FASEB J. 4: 3215-3223

19. Mukhopadhyay T, Roth JA and Maxwell SA (1996) Induction of p53 DNA-binding activity by tumor necrosis factor- $\alpha$. Int. J. Oncol. 9: 715-720

20. Pahl HL (1999) Activators and target genes of Rel/NF- $k B$ transcription factors. Oncogene 18: 6853-6866

21. Lin B, Williams-Skipp C, Tao Y, Schleicher MS, Cano LL, Duke RC and Scheinman RI (1999) NF- $k$ B functions as both a proapoptotic and antiapoptotic regulatory factor within a single cell type. Cell Death Differ 6: 570-582

22. Cobb M, Robbins D and Boulton T (1991) ERKs, extracellular signal-regulated MAP-2 kinases. Curr. Biol. 3: 1025-1032

23. Derijard B, Hibi M, Wu I, Baret T, Su B, Deng T, Karin Mand Davis R (1994) JNK1: A protein kinase stimulated by UV light and Ha-Ras that binds and phosphorilates the c-Jun activation domain. Cell 76: 1025-1037

24. Coso OA, Chiariello M, Kalinec G, Kyriakis JM, Woodgett J and Gutkind S (1995) Transforming G protein-coupled receptors potently activate JNK (SAPK). J. Biol. Chem. 270: 5620-5624

25. Coso O, Chiariello M, Yu J, Teramoto H, Crespo P, Xu N, Miki T and Gutkind JS (1995) The small GTP-binding proteins Rac and Cdc42 regulate the activity of the JNK (SAPK) signaling pathway. Cell 81: 1137-1146
26. Ono $\mathrm{K}$ and Han J (2000) The p38 signal transduction pathway activation and function. Cellular signalling 12:1-13

27. Nebreda AR and Porras A (2000) p38 MAP kinases: beyond the stress response. TIBS 25: $257-260$

28. Kültz D and Burg M (1998) Evolution of osmotic stress signaling via MAP kinase cascades. J. Exp. Biol. 201: 3015-3021

29. Bode JG, Gatsios P, Ludwig S, Rapp UR, Häussinger D, Heinrich PC and Graeve $L$ (1999) The mitogen-activated protein (MAP) kinase p38 and its upstream activator MAP kinase kinase 6 are involved in the activation of signal transducer and activator of transcription by hyperosmolarity. J. Biol. Chem. 274: 3022230227

30. Berghe WV, Plaisance S, Boone E, De Bosscher K, Schmitz ML, Fiers W and Haegeman G (1998) p38 and extracellular signal-regulated kinase mitogenactivated protein kinase pathways are required for nuclear factor- $k B$ p65 transactivation mediated by tumor necrosis factor. J. Biol. Chem. 273: 32853290

31. Downward J (1998) Ras signaling and apoptosis. Curr. Opin. Genet. Dev. 8:4954

32. Cuvillier O, Pirianov G, KleuserB, VanekPG, Coso OA, Gutkind JS and SpiegelS (1996) Suppression of ceramide-mediated programmed cell death by sphingosine-1-phosphate. Nature 381: 800-803

33. Monney L, Olivier R, Otter I, Jansen B, Poirier G and Borner C (1998) Role of an acidic compartment in tumor-necrosis-factor- $\alpha$-induced production of ceramide, activation of caspase-3 and apoptosis. Eur. J. Biochem. 251: 295-303

34. Green D (1998) Apoptotic pathways: the roads to ruin. Cell 94: 695-698

35. Gross A, McDonnell JM and Korsmeyer SJ (1999) BCL-2 family members and the mitochondria in apoptosis. Genes Dev. 13: 1899-1911

36. Gerritsen ME, Williams AJ, Neish AS, Moore NS, Shi Y and Collins T (1997) CREB-binding protein/p300 are transcriptional co-activators of p65. Proc. Natl. Acad. Sci. USA 94: 2927-2932

37. Bortner CD, Hughes FM and Cidlowski JA (1997) A primary role for $\mathrm{K}^{+}$and $\mathrm{Na}^{+}$ effflux in the activation of apoptosis. J. Biol. Chem. 272: $32436-32442$

38. Bortner CD and Cidlowski JA (1998) A necessary role for cell shrinkage in apoptosis. Biochem. Pharmacol. 56: 1549-1559

39. Bortner $\mathrm{CD}$ and Cidlowski JA (2000) Volume regulation and ion transport during apoptosis. Methods Enzymol. 322: 421-433

40. Okada Y, Maeno E, Shimizu T, Dezaki K, Wang J and Morishima S (2001) Receptor-mediated control of regulatory volume decrease (RVD) and apoptotic volume decrease (AVD). J. Physiol. 532: 3-16

41. Montague JW, Bortner CD, Hughes Jr FM and Cidlowski JA (1999) A necessary role for reduced intracellular potassium during the DNA degradation phase of apoptosis. Steroids 64: $563-569$

42. Kültz D, Madhany S and Burg MB (1998) Hyperosmolality causes growth arrest of murine kidney cells. J. Biol. Chem. 273: 13645-13651

43. Carter AB, Knudtson KL, Monick MM and Hunninghake GW (1999) The p38 mitogen-activated protein kinase is required for NF- $k \mathrm{~B}$-dependent gene expression. J. Biol. Chem. 274: 30858-30863

44. Polla BS, Jacquier-Sarlin MR, Kantengwa S, Mariethoz E, Hennet T, RussoMarie F, Cossarizza A (1996) TNF alpha alters mitochondrial membrane potential in L929 but not in TNF alpha-resistant L929.12 cells: relationship with the expression of stress proteins, annexin 1 and superoxide dismutase activity. Free Radic. Res. 25: 125-131

45. Albrecht H, Tschopp J and Jongeneel V (1994) Bcl-2 protects from oxidative damage and apoptotic cell death without interfering with activation of NF- $\kappa$ B by TNF. FEBS Letters 351: 45-48

46. Wahl C, Liptay S, Adler G and Schmid R (1998) Sulfasalazine: a potent and specific inhibitor of nuclear factor kappa B. J. Clin. Invest. 101: 1163-1174 